\title{
EFL Pre-Service Teachers' Perception of Their Readiness in Teaching Online during Covid-19 Pandemic
}

\author{
Ni Komang Sarini Dewi \\ Universitas Pendidikan Ganesha, Indonesia \\ sarinidewi2@gmail.com
}

\begin{abstract}
As teacher candidate, students majoring in English Education is required to take a teaching practice in real classroom setting. However, due to Covid-19 pandemic, the scheme of teaching practice is changed to online setting. The current study investigated pre-service teachers' perception of their readiness in teaching English online. This study was a qualitative study followed by five English teacher candidate. The data were collected using interview guide and were analyzed using thematic analysis. It was found that the pre-service teachers were already familiar with the use technology for teaching such as google classroom, Schoology, and Zoom. They mentioned that in terms of pedagogy, they are still uncertain about their readiness because of their lack experience. The study highlighted that the role of supervision in really importance in enhancing pre-service teachers' competencies.
\end{abstract}

Keywords: EFL, Pre-Service Teacher, Readiness

\section{INTRODUCTION}

Students majoring in English education in Indonesia have an obligation to carry out teaching practices in order to fulfill the requirements for completing the study. This teaching practice is usually carried out in elementary to senior high school level. However, the COVID-19 pandemic has changed the teaching practice scheme (Flores \& Swennen, 2020). Students now have to understand about how to implement online teaching which is very different from teaching face to face (Almaiah et al., 2020; Hill, 2021). The implementation includes how to use technology and how to take advantages of technology in online teaching situations (Karataş \& Tuncer, 2020).

According to Ogbonnaya et al., (2020), the difference between online and face-to-face teaching can be seen from the form of interaction, teaching strategies, and forms of assessment. Students also need to be aware of this difference so that they are able to adapt to online teaching situations. Besides that, prospective teachers must also be ready to teach online (Kebritchi et al., 2017). This includes being ready to know how to teach online and being technically ready in the context of mastering technology for teaching purposes (Harris \& Hofer, 2011; Hsu, 2016).

Readiness of students as future teacher in the context of online teaching can be measured by several approaches. Misieng et al., (2018) suggested the use of TPACK (Technology, Pedagogy and Content Knowledge) approach in identifying readiness of teaching online with the use of technology. TPACK which was developed by Mishra and Koehler (2006) focused on how the teacher can integrate technology into teaching and learning activities. Al-Furaydi (2013) used TAM (Technology Acceptance Model) in measuring teacher readiness in inserting technology into e-learning. TAM was intended to give prediction about the 
technology acceptance level and consisted of four constructs namely perceived ease of use, perceived usefulness, attitudes, and actual behaviors (Deslonde \& Becerra, 2018; Wan Azli et al., 2018).

Based on the results of interviews with several pre-service teachers, they revealed that teaching online was their first experience. Previously, at the university where they studied, teaching practice in the form of micro teaching was carried out face-to-face. They also revealed that they received little training on how to teach online because online teaching is not widely applied in both primary and secondary schools. Judging from the statements of pre-service teachers, it is important to conduct a study that identifies their readiness to teach online. By conducting this study, it is hoped that students can see their level of readiness in online teaching and take appropriate steps to improve online teaching competence.

\section{METHOD}

\section{Design}

The current study was a qualitative study aimed at investigating EFL pre-service teachers' perception of their readiness in teaching online. This study was followed by five EFL pre-service teachers who were randomly selected as the participants of the study. The pre-service teachers were doing teaching practice when this study was being undertaken.

\section{Instruments}

In collecting the data, this study used interview guide. The interview technique used was a semi-structured interview. The questions of the interview were developed based TPACK approach (Thinzarkyaw, 2020). The list of questions can be seen in Table 1.

\section{Table 1. Interview Guide}

Are you familiar with technology in teaching?

2. Are you ready to integrate technology in your online classroom?

3. How is your teaching style?

4. Are you ready to adjust your teaching style to online setting?

5. Overall, do you see your self ready to teach English using technology in online setting?

\section{Data Analysis}

The data from the interview were analyzed using thematic analysis. A thematic analysis focuses on identifying theme and patterns of data through four stages namely data collection, transcribing, re-reading, analyzing and interpreting data (Evans, 2017)

\section{FINDINGS \& DISCUSSIONS}

After analyzing the data, there were several themes identified. The first theme was familiarity of technology in language teaching. As the students said:

I know a little bit about technology in teaching English. I heard many times about Mobile Assisted Language Learning 


\begin{abstract}
Some platforms in online teaching I know are google classroom and Schoology (T5)

I know some application that I used in my micro teaching practice such as Kahoot, Zoom and Google Classroom.
\end{abstract}

From the responses, it can be said that the students-teacher are familiar with tools and platform of technology in classroom. They know learning platform such as Google Classroom and Schoology. They also mentioned that they are currently implementing those platforms supported with mobile device. Mastering technology is very important for teachers during this pandemic considering that learning is carried out online (König et al., 2020).However, mastering technology can be stressful for teachers because lack of digital literacy and training (Fernández-Batanero et al., 2021).

Mastering technology for teaching purposes is an important asset for preservice teachers (Schmidt et al., 2009). They need to know the types of technology that can be used and in accordance with learning objectives and student competencies (Ghavifekr \& Rosdy, 2015). Technology, when used properly, will be able to improve the quality of teaching and the learning experience will be even better for prospective teachers and students (Qurat-ul-Ain et al., 2019)

The second theme appear from the result of interview was readiness of integrating pedagogy and technology. The respondents said:

Ready or not, I have to adapt my teaching method to the online situation. (T1)

Technologically, I am ready but for pedagogy maybe not completely because this is a new experience for me teaching online. (T4)

As a teacher, I have to be ready for any changes in the teaching and learning system. (T3)

It can be said that from students' responses, they are ready to teach English online. However, one teacher mentioned that in terms of pedagogy, it might be quite different from what they had learnt in college. This was also their first teaching experience in real setting. Dorsah (2021) states that pre-service teachers need to be ready in teaching online in emergency setting due to Covid19 pandemic. This was also supported by Buzdar et al., (2016) who stated that preparation is the most vital element of carrying out online instructions. In carrying out teaching practice, the students said:

I really need a companion lecturer to support online teaching readiness. I can ask a lot of my lecturers about how to teach online properly and correctly. (T1)

I hope in the early days of teaching practice, I am accompanied by teachers and lecturers in online classes. So I can get feedback on how I teach online (T2) 
As a teacher, I have to be ready for any changes in the teaching and learning system. (T3)

During the teaching practice period, student teacher candidates hope to be accompanied by a teacher or lecturer. According to students, this mentoring is very important because students can discuss and get feedback about the online teaching process that will be implemented. Latifah (2014) supervising pre-service teachers could enhance their teaching skills. This can be done by sharing experiences and giving comments towards pre-service teachers' performance. Supervising could be also the reflective process for pre-service teachers in order to improve their pedagogy, personal, professional and social competency (Hamel, 2012; Ratminingsih et al., 2017).

\section{CONCLUSIONS}

The current study was focused on identifying pre-service teachers' perception towards their readiness in online teaching. It was found that, the preservice teachers when this study was conducted, they were preparing for teaching practice online. It was also identified that pre-service teacher already familiar with technology in online teaching and they already implemented some platform of online teaching such as google classroom, Schoology and zoom. In terms of technological readiness, they see themselves are ready to carry out online teaching. However, in terms of pedagogical readiness, they still uncertain about their readiness because of this would be their first experience in teaching English online. The pre-service teachers also asked for the companion from their supervisors in carrying out online teaching.

\section{REFERENCES}

Al-Furaydi, A. A. (2013). Measuring E-learning readiness among EFL teachers in intermediate public schools in Saudi Arabia. English Language Teaching, 6(7), 110-121. https://doi.org/10.5539/elt.v6n7p110

Almaiah, M. A., Al-Khasawneh, A., \& Althunibat, A. (2020). Exploring the critical challenges and factors influencing the E-learning system usage during COVID-19 pandemic. Education and Information Technologies, 25(6), 52615280. https://doi.org/10.1007/s10639-020-10219-y

Buzdar, M. A., Ali, A., \& Tariq, R. U. H. (2016). Emotional intelligence as a determinant of readiness for online learning. International Review of Research in Open and Distance Learning, 17(1), 148-158. https://doi.org/10.19173/irrodl.v17i1.2149

Deslonde, V., \& Becerra, M. (2018). The Technology Acceptance Model (TAM): Exploring School Counselors' Acceptance and Use of Naviance. The Professional Counselor, 8(4), 369-382. https://doi.org/10.15241/vd.8.4.369

Dorsah, P. (2021). Pre-service Teachers' Readiness for Emergency Remote Learning in the Wake of COVID-19. European Journal of STEM Education, 6(1), 01. https://doi.org/10.20897/ejsteme/9557

Evans, C. (2017). Analysing Semi-Structured Interviews Using Thematic Analysis: Exploring Voluntary Civic Participation Among Adults. In J. Lewis (Ed.), SAGE Research Methods Datasets Part 1. SAGE Pub. https://doi.org/10.4135/9781526439284

Fernández-Batanero, J. M., Román-Graván, P., Reyes-Rebollo, M. M., \& Montenegro-Rueda, M. (2021). Impact of educational technology on teacher 
stress and anxiety: A literature review. International Journal of Environmental Research and Public Health, 18(2), 1-13. https://doi.org/10.3390/ijerph18020548

Flores, M. A., \& Swennen, A. (2020). The COVID-19 pandemic and its effects on teacher education. European Journal of Teacher Education, 43(4), 453-456. https://doi.org/10.1080/02619768.2020.1824253

Ghavifekr, S., \& Rosdy, W. A. W. (2015). Teaching and learning with technology: Effectiveness of ICT integration in schools. International Journal of Research in Education and Science, 1(2), 175-191. https://doi.org/10.21890/ijres.23596

Hamel, C. (2012). Supervision of pre-service teacher: Using internet collaborative tools to support their return to their region of origin. Canadian Journal of Education, 35(2), 141-154.

Harris, J. B., \& Hofer, M. J. (2011). Technological Pedagogical Content Knowledge (TPACK) in Action: A Descriptive Study of Secondary Teachers' Curriculum-Based, Technology-Related Instructional Planning. 43(3), 211 229.

Hill, J. B. (2021). Pre-Service Teacher Experiences during COVID 19: Exploring the Uncertainties between Clinical Practice and Distance Learning. Journal of Practical Studies in Education, 2(2), 1-13. https://doi.org/10.46809/jpse.v2i2.18

Hsu, L. (2016). Examining EFL teachers' technological pedagogical content knowledge and the adoption of mobile-assisted language learning: a partial least square approach. Computer Assisted Language Learning, 29(8), 12871297. https://doi.org/10.1080/09588221.2016.1278024

Karataş, T. Ö., \& Tuncer, H. (2020). Sustaining language skills development of pre-service EFL teachers despite the COVID-19 interruption: A case of emergency distance education. Sustainability (Switzerland), 12(19). https://doi.org/10.3390/su12198188

Kebritchi, M., Lipschuetz, A., \& Santiague, L. (2017). Issues and Challenges for Teaching Successful Online Courses in Higher Education. Journal of Educational Technology Systems, 46(1), 4-29. https://doi.org/10.1177/0047239516661713

König, J., Jäger-Biela, D. J., \& Glutsch, N. (2020). Adapting to online teaching during COVID-19 school closure: teacher education and teacher competence effects among early career teachers in Germany. European Journal of Teacher Education, 43(4), 608-622. https://doi.org/10.1080/02619768.2020.1809650

Latifah, D. (2014). The Role of In-Service Teacher in Supervising Pre-Service Teachers during Teaching Practicum Program. Harmonia: Journal of Arts $\begin{array}{llll}\text { Research and } & \text { Education, } & \end{array}$ https://doi.org/10.15294/harmonia.v14i2.3290

Mishra, P., \& Koehler, M. J. (2006). Technological Pedagogical Content Knowledge: A Framework for Teacher Knowledge. 108(6), 1017-1054.

Misieng, J.-, Ramanair, J., \& Rethinasamy, S. (2018). Measuring teachers' readiness to use technology. Journal of IT in Asia, 8(1), 7-13. https://doi.org/10.33736/jita.852.2018

Ogbonnaya, U. I., Awoniyi, F. C., \& Matabane, M. E. (2020). Move to online learning during covid-19 lockdown: Pre-service teachers' experiences in ghana. International Journal of Learning, Teaching and Educational 
Research, 19(10), 286-303. https://doi.org/10.26803/IJLTER.19.10.16

Qurat-ul-Ain, Shahid, F., Aleem, M., Islam, M. A., Iqbal, M. A., \& Yousaf, M. M. (2019). A review of technological tools in teaching and learning computer science. Eurasia Journal of Mathematics, Science and Technology Education, 15(11). https://doi.org/10.29333/ejmste/109611

Ratminingsih, N. M., Artini, L. P., \& Padmadewi, N. N. (2017). Incorporating self and peer assessment in reflective teaching practices. International Journal of Instruction, 10(4), 165-184. https://doi.org/10.12973/iji.2017.10410a

Schmidt, D. A., Baran, E., Thompson, A. D., Mishra, P., Koehler, M. J., \& Shin, T. S. (2009). Technological Pedagogical Content Knowledge (TPACK): The Development and Validation of an Assessment Instrument for Preservice Teachers. Journal of Research on Technology in Education, 42(2), 123-149.

Thinzarkyaw, W. (2020). The practice of technological pedagogical content knowledge of teacher educators in education colleges in Myanmar. Contemporary Educational Technology, 11(2), 159-176. https://doi.org/10.30935/cet.660829

Wan Azli, W. U. A., Shah, P. M., \& Mohamad, M. (2018). Perception on the Usage of Mobile Assisted Language Learning (MALL) in English as a Second Language (ESL) Learning among Vocational College Students. Creative Education, 09(01), 84-98. https://doi.org/10.4236/ce.2018.91008 